\title{
Retroviral matrix and lipids, the intimate interaction
}

\author{
Elise Hamard-Peron, Delphine Muriaux ${ }^{*}$
}

\begin{abstract}
Retroviruses are enveloped viruses that assemble on the inner leaflet of cellular membranes. Improving biophysical techniques has recently unveiled many molecular aspects of the interaction between the retroviral structural protein Gag and the cellular membrane lipids. This interaction is driven by the N-terminal matrix domain of the protein, which probably undergoes important structural modifications during this process, and could induce membrane lipid distribution changes as well. This review aims at describing the molecular events occurring during MA-membrane interaction, and pointing out their consequences in terms of viral assembly. The striking conservation of the matrix membrane binding mode among retroviruses indicates that this particular step is most probably a relevant target for antiviral research.
\end{abstract}

\section{Introduction}

Retroviruses are enveloped single-stranded RNA (+) viruses; they include some human pathogens such as human immunodeficiency virus (HIV), and oncoviruses such as the murine leukemia virus (MLV). Regardless of their diversity and the high divergence in their sequences, they share functional and viral protein structure similarities. Their genome contains the three retroviral genes: gag, pol, and env, and regulatory proteins in the case of complex retroviruses. One of the important steps in the process of retoviral infection is the formation of new infectious particles. It consists of the assembly of the viral core at the cellular membrane, budding, and maturation of the viral particles. In this review, we will focus especially on the events that occur at the molecular level during the interaction between Gag and membranes, more particularly between the Matrix domain of retroviral Gag proteins and the phospholipids, and we will place it in the context of the viral assembly process. Retroviral assembly relies on the viral Gag protein, and especially its ability to interact with the viral genomic RNA (gRNA) and cellular membranes. Gag is a polyprotein with three domains: the matrix domain, MA, that binds membranes, the capsid domain, CA, that contains Gag multimerization motifs and is responsible for the viral capsid formation (see [1] for

\footnotetext{
* Correspondence: delphine.muriaux@ens-lyon.fr

Human Virology Department, Inserm U758, Ecole Normale Superieure de Lyon, 36 Allee d'Italie, IFR128, Universite de Lyon, Lyon, France
}

review), and the nucleocapsid domain, NC, that recruits the RNA genome and also promotes Gag multimerization $[2,3]$. The assembly process most probably initiates with the formation of a ribonucleoprotein complex composed of a few Gag molecules and the gRNA, which is going to interact with membranes $[4,5]$. Beta-retroviruses and spumaviruses are exceptions, that fully assemble in the cytosol before reaching membranes (see [6] for review on spumaviruses, and [7] for study on the role of MA in promoting cytosolic assembly of MPMV). The formation of higher order Gag multimers leads to the formation of the viral particle at the plasma membrane, and subsequent budding and maturation, which consist of the proteolytic cleavage of Gag and structural rearrangement of the particle. The MA domain is not only carrying Gag trafficking and membrane binding determinants, but also dictating the specificity of the bound lipid. Many data have been recently published partially unveiling the molecular mechanism of MA lipid binding, enhancing the understanding of the role played by MA during Gag membrane targeting and assembly. In the light of the literature and our experiences, this review aims at proposing biochemical models for MA-lipid interactions for different retroviruses, and replacing the consequences of such interactions in the context of retroviral assembly. We will identify the elements conserved through retroviral evolution, and those that are specific to particular retroviral strains.
C Biomed Central

() 2011 Hamard-Peron and Muriaux; licensee BioMed Central Ltd. This is an Open Access article distributed under the terms of the Creative Commons Attribution License (http://creativecommons.org/licenses/by/2.0), which permits unrestricted use, distribution, and reproduction in any medium, provided the original work is properly cited. 


\section{Matrix proteins: a structural point of view}

Despite low sequence similarity, MAs from different retroviruses share a conserved function in anchoring the viral Gag polyprotein to the plasma membrane. Indeed, most Gag chimeras with heterologous MA domains remain able to drive particle assembly [8-11]. One element allowing the interaction with the cellular membrane is N-terminal myristylation, a post-tranlational modification found in MAs from all retroviral families (myrMAs), including human immunodeficiency virus (HIV) [12], human T-lymphotropic virus (HTLV) [13], Mason-Pfizer monkey virus (M-PMV) [14] and exogenous murine leukemia virus (MLV) strains $[15,16]$. This myristate moiety is a common signal for membrane targeting of proteins, as it can insert into membrane bilayers. There are some exceptions, however, as Rous sarcoma virus (RSV), Visna virus, caprine arthritis-encephalitis virus (CAEV) and equine infectious anemia virus (EIAV) MAs are not myristylated [14]. Therefore, myristylation cannot be the only element involved in this targeting. Structural analysis of MA domains offers some clues for understanding its conserved biological role regarding membrane anchoring. Matrix structures from nine retroviruses have been resolved to date: HIV1 [17-20] and 2 [21], SIV [22], HTLV-2 [23], bovine leukemia virus (BLV) [24], M-PMV [25], RSV [26], EIAV [27], and MLV [28]. They are all made of a globular core composed of four $\alpha$-helices, whose overall organization is conserved among the retroviridae family $[29,30]$ as shown by the superimposition Figure $1 \mathrm{~A}$. In the case of HIV-1, the unmyr-MA structure was resolved both by NMR $[17,18]$ and crystallography [19], while the myr-MA structure was resolved by NMR only [20]. HIV-1 unmyr-MA (as well as SIV, but neither EAIV nor MLV MAs) crystallized as trimers, while it appeared mainly monomeric in classical NMR conditions. Overall structure was conserved between myr and
unmyr-MA, but some differences arose, notably in the putative trimerization region and in the first alpha helix. As suggested earlier by Zhou and Resh [31], Tang and colleagues [20] showed that there is an equilibrium between two conformations of HIV-1 myrMA in solution. In the myr[s] conformation, the myristate moiety is sequestrated inside the core of the protein (see scheme in Figure 1B). This is the conformation adopted by the majority of myr-MA at a concentration of 150-200 $\mu \mathrm{M}$. The other conformation, myr[e], promotes the exposure of the myristate and tends to assemble in trimers. This conformation is probably close to the conformation observed for unmyr-MA. The conversion from one state to the other is entropically regulated [20]. In particular, high concentration of MA (more than $400 \mu \mathrm{M}$ ) promotes trimerization and stabilizes the myr[e] conformation. This will be extensively discussed in the next sections. Whether these myr[s] and myr[e] conformations exist for other retroviral MAs has never been demonstrated formally. However, a NMR study carried out on EIAV-MA (which is not myristylated) evidenced amino acid shifts at high MA concentration, and correlated with an increase of the trimeric versus monomeric state [32]. Even if no major conformation change was noticed, this may correspond to an entropic switch between two slightly different conformations, similar to HIV. We, therefore, propose a new nomenclature for the MA conformations, that can also apply for unmyristylated MAs. By analogy with the enzymology, the membrane-binding prone conformation will be denoted hereafter as relaxed $[R]$, while the other conformation will be denoted as tensed [T] (Figure 1B). Another important element of MA necessary for membrane binding is most probably the highly basic region (HBR). Indeed, an exposed patch of basic amino acids has been observed or predicted on all retroviral MAs [30]. A comparison between structurally superimposed
A

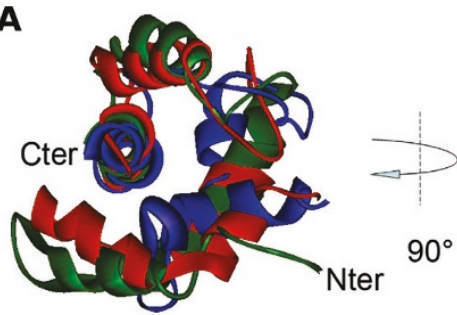

$\sum M L V$

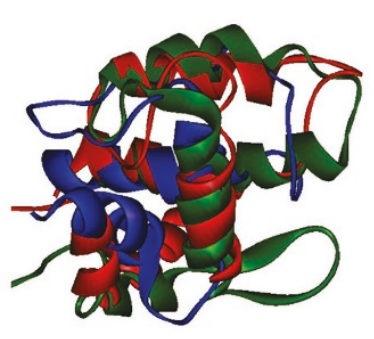

$\sum R S V$
B
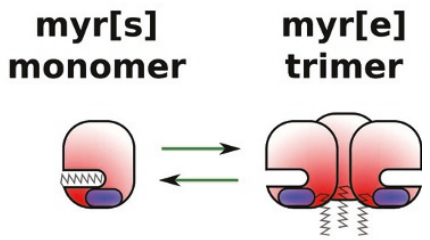

[T]

Figure 1 A structural overview of retroviral MAs. (A): Structural superimposition of MLV (1MN8), RSV (1A6S) and HIV (1TAM) MA proteins, Superimposition obtained using the combinatorial extension method (CE) and the image was generated with Viewer Pro software (Accelrys), thanks to E. Derivery. (B): Scheme of the [T] to [R] switch. (T] conformation sequesters the myristate of myristylated MAs, and remains monomeric, while $[\mathrm{R}]$ conformation associates in trimers and exposes the myristate (when present). 
retroviral MAs shows that this domain "migrates" on the surface of the protein, but is always found in the proximity of the N-terminus [30]. This supports the idea that the $\mathrm{N}$-terminus and the polybasic region of MA cooperate for efficient membrane binding, as HBR was hypothetized to promote interaction of MA with acidic phospholipid heads [30]. Moreover, other amino acids could be involved in Gag membrane anchoring, such as the N-terminal amino acids invovled in [T] to [R] conversion in HIV-MA [33,34].

\section{Acidic lipid binding: the biochemical characterization}

In cells, analysis confirmed that Gag membrane binding depends on this bipartite signal for most retroviruses. On one hand, the myristate moiety is, as expected, necessary to ensure membrane binding for all myristylated MAs, as shown for MLV [16,35], HIV [36], or M-PMV [37]. On the other hand, mutations in the HBR disrupted Gag membrane-binding and assembly of HIV [38-41], MLV $[42,43]$, feline immunodeficiency virus (FIV) [44], RSV
[45], HTLV-1 [46] and M-PMV [47], suggest that MA may interact with acidic membrane lipids.

To precisely identify the lipids that interact with retroviral Gag proteins, researchers focused on the lipids potentially present at the budding site. Phospholipids, including glycerophospholipids and sphingolipids, are the main components of cellular membranes, among which the most abundant are phosphatidylcholine (PC) and phosphatidylethanolamine (PE), both containing a neutral polar head. Some less abundant species, however, like phosphatidyl serine (PS), phosphatidyl glycerol (PG) or phosphatidylinositol phosphates (PIPs), contain acidic polar heads (cf. Figure 2). Apart from phospholipids, cellular membranes also contain other lipids, such as cholesterol, and an important proportion of transmembrane proteins. The composition of a membrane depends on its localization (internal/plasma membrane, inner/outer leaflets, etc.) and defines its functionality. Thus, retroviral assembly location restricts the panel of lipids potentially involved in the interaction with MA. Indeed, budding is mainly observed at the plasma

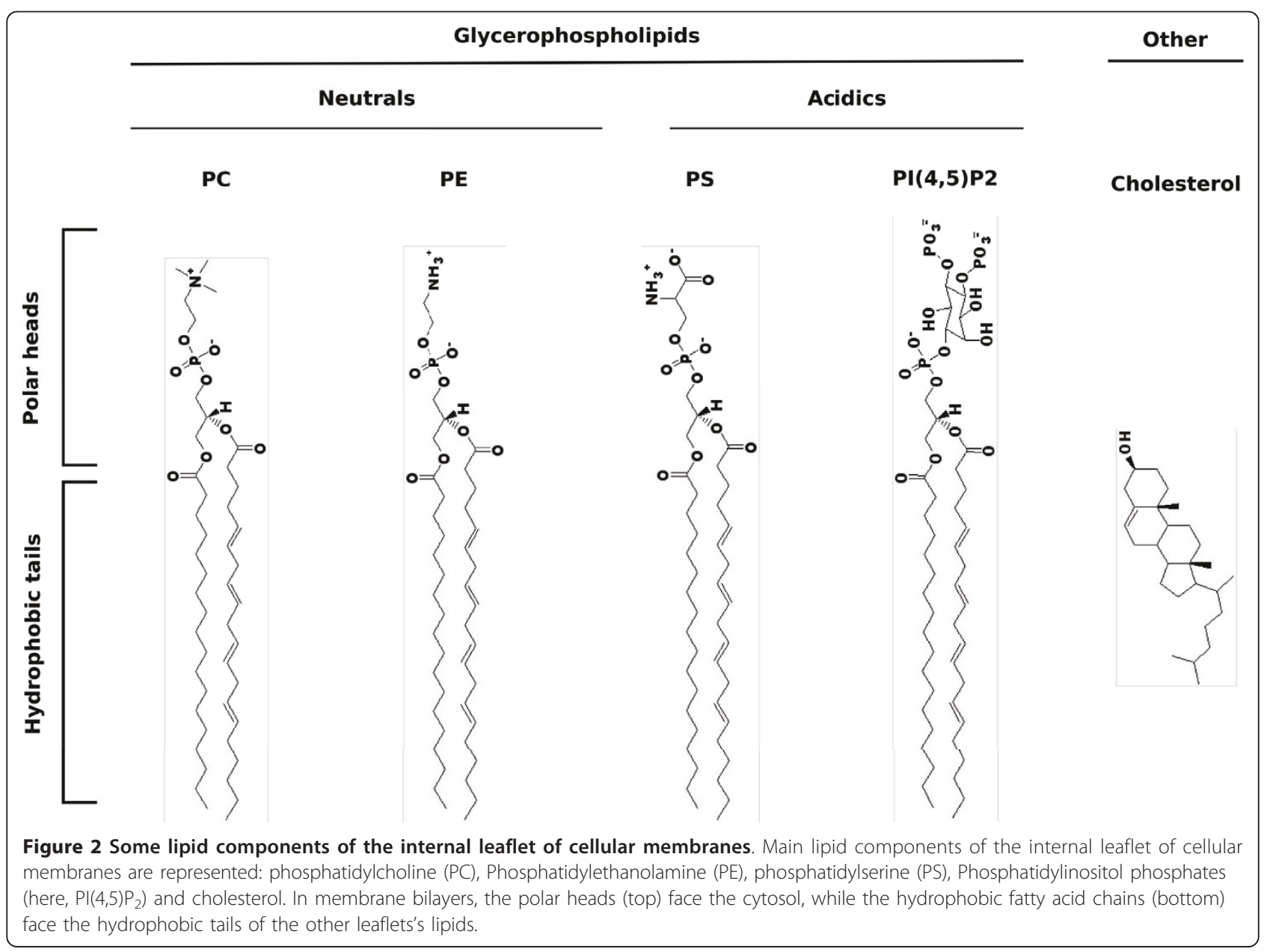


membrane for most retroviruses, including HIV [48], MPMV, MLV [42,49], FIV, RSV, HTLV, but may also occur on internal membranes such as endosomes (see [50] and [51] for review). Moreover, the MA domain of Gag interacts with the inner leaflet of cellular membranes, whose main lipids are PC, PE, PS, PIP (here PI $\left.(4,5) \mathrm{P}_{2}\right)$, and cholesterol [52], thereby succeptible to interact with MA (Figure 2).

Interaction between proteins and lipids can be studied in vitro using biomimetic membranes, and in particular large unilamellar vesicles (see [53] for review on using LUVs). The dissociation constant (Kd) can be measured, and corresponds to the lipid concentration at which half the protein is associated with the lipids: the lower the $\mathrm{Kd}$, the higher the affinity. Most experiments were performed using recombinant MA proteins, because purification of the entire Gag protein is not easy. MA domain is separated from the rest of Gag by a flexible linker, thus isolated recombinant MA should recapitulate most functions of MA domain in Gag. It must be taken into account, however, that HIV-MA alone seems to have decreased affinity for membranes in comparison to the entire Gag [31]. Recombinant MA is also directly representative of the maturated MA domain function in mature particles and during early stage of viral infection. As expected, purified recombinant MAs from RSV [54] and HIV-1 $[55,56]$ can bind containing an acidic phospholipid, the phosphatidylserine (PS), which is an abundant specy in the internal layer of cellular membranes. The order of magnitude of the Kd measurements made for recombinant RSV-MA and HIV-1 myristylated MA (myrMA) were of $10_{-}^{3} \mathrm{M}$, and about one order of magnitude lower upon forced dimerization of MA $[54,55]$. Nevertheless, the method used in these studies, i.e. LUV flotation, may underestimate the actual affinity, as the sucrose gradient may dilute the lipids. Indeed, we and others reported a value closer to $10{ }_{-}^{5} \mathrm{M}$ for unmyristylated HIV MA (HIV unmyrMA) by sedimentation assay [42] or by intrinsic fluorescence measurement $[56,57]$. Ehrlich and colleagues [56] showed that HIV-1 MA is also able to bind in vitro to another basic phospholipid, the phosphatidylglycerol (PG). These later studies were contested, however, because the authors also observed a binding of the CA domain of Gag to PG and PS that other authors questioned [54]. Recently, Barrera and colleagues [58] confirmed that CA has acidic lipid binding properties $[58,59]$, rehabilitating the previous findings. It was also reported that EIAV MA can interact with PS $\left(\mathrm{Kd}<10_{-}^{6} \mathrm{M}\right.$ at $\left.0.1 \mathrm{M} \mathrm{NaCl}\right)$ and $\mathrm{PC}[60]$.

The binding of retroviral MAs to lipids was thus considered to be purely electrostatic, as the interaction with PS was inhibited at high ionic strength. The Kd values found would fit well with the computational models considering electrostatic interaction between acidic lipids and basic MAs [30]. These reported Kd values would be rather low, though, to fully explain the binding of Gag to the plasma membrane in cells, and multimerization was invoked to explain MA binding to membranes $[54,55]$.

Several retroviruses, however, show a dependency on a particular acidic phospholipid, the $\mathrm{PI}(4,5) \mathrm{P}_{2}$, for efficient particle production in cells. These include HIV $[61,62]$, M-PMV [47] and MLV [42,62]. Phosphatidylinositol phosphates are a family of acidic glycerophospholipids, with a polar head made of an inositol ring that can be mono-, bi-or tri-phosphorylated (Figure 2 shows the example of $\left.\mathrm{PI}(4,5) \mathrm{P}_{2}\right)$. The sub-cellular localization of the different species is highly regulated by cellular kinases and phosphatases, such that they stand as major determinants of the identity of organelles' membranes (see [63], [64] and [65] for review).

The interaction between MAs and $\mathrm{PI}(4,5) \mathrm{P}_{2}$ has been observed in vitro by NMR (EIAV [32], HIV-1 [66] and HIV-2 [21]), using LUVs (HIV-1 [67-69] and MLV [42]), by mass spectrometric footprinting (HIV-1 [70]) and by surface plasmon resonance (SPR)(HIV-1, [71]). The Kd values measured by NMR were rather high for all tested lentiviruses (EIAV, HIV-1, and HIV-2), ranging from 125 to $185 \mu \mathrm{M}$, and cannot account for membrane binding in cells. It is noteworthy though that these interactions were observed with short chain PIPs (Di-C4-PI $\left.(4,5) \mathrm{P}_{2}\right)$. In contrast, SPR analysis was performed both with $\mathrm{Di}$-C4-and Di-C8-PI $(4,5) \mathrm{P}_{2}$ (longer acyl chains), and $\mathrm{Kd}$ values decreased significantly in the case of Di-C8-PI $(4,5) \mathrm{P}_{2}$, suggesting that acyl chains are involved in the interaction between MA and $\mathrm{PI}(4,5) \mathrm{P}_{2}$ [71]. The Kd of this interaction could not be calculated in the LUV systems, however, neither for the recombinant HIV MA domain $[42,55]$, nor for the recombinant RSV MA domain [54]. This suggests that unlike PS binding, the mechanism of PIP/HIV-MA interaction could be more complex than a simple electrostatic interaction. The region of HIV-MA involved in the interaction with $\mathrm{PI}(4,5) \mathrm{P}_{2}$ differs slightly depending on the method used (NMR [66] or footprinting [70]), but mapped to the HBR in both cases. New NMR techniques, using reverse micelle encapsidation instead of soluble lipids could settle it, but only preliminary results have been published to date [72].

We recently reported a definite different behavior in the case of MLV-MA [42]. UnmyrMLV-MA was able to bind PIPs-containing LUVs in a dose-dependant manner. An interaction is observed not only with $\mathrm{PI}(4,5) \mathrm{P}_{2}$, but also with all the PIPs species, with $\mathrm{Kd}$ values ranging from 20 to $50 \mu \mathrm{M}$. To the contrary, unmyrMLV-MA does not bind PS containing LUVs, even if the residues involved in the interaction with PIPs map to the HBR. However, adding $\mathrm{PI}(4,5) \mathrm{P}_{2}$ and PS together in the same LUV dramatically increased the affinity of MLV-MA for $\mathrm{PI}(4,5) \mathrm{P}_{2}$, but not 
for the other PIPs. Therefore, as for HIV, interaction with PIPs appears to result from a specific interaction, rather than a purely electrostatic mechanism [42].

\section{Specificity and regulation of the interaction with acidic phospholipids}

In the light of the data presented above, we can question the specificity and the biological relevance of the interaction of retroviral Gag with the different acidic phospholipid species, as MA can interact in vitro with different acidic phospholipids, with important differences in $\mathrm{Kd}$ and interaction mode.

The lipidomics data emerging from the analysis of viral particles, however, seems to confirm the specificity for both $\mathrm{PI}(4,5) \mathrm{P}_{2}$ and $\mathrm{PS}$, as they are highly enriched in MLV particles [73]. This is consistent with the in vitro data obtained with MLV-MA, showing that there is in fact a cooperation between $\mathrm{PI}(4,5) \mathrm{P}_{2}$ and $\mathrm{PS}$ which allows strong MA anchoring to the membrane. Indeed, even if MLV-MA can bind any PIPs but not PS-containing LUVs, the protein actually displayed a strong stereospecificity for $\mathrm{PI}(4,5) \mathrm{P}_{2}$, but exclusively when $\mathrm{PS}$ is added to the same LUV (resulting in a fourfold decrease in $\mathrm{Kd},[42])$. Thus, MA probably interacts with both PI $(4,5) \mathrm{P}_{2}$ and PS, but we hypothesize that PS binding may occur only after initial docking of MA on the $\mathrm{PI}(4,5) \mathrm{P}_{2}$. In HIV particles, $\mathrm{PI}(4,5) \mathrm{P}_{2}$ is enriched, while PS is present at high concentrations. Together with data emerging from MLV study, these results indicate that in vitro binding of HIV-MA to both $\mathrm{PI}(4,5) \mathrm{P}_{2}$ and PS may be biologically relevant. Other families of lipids may also regulate MA association with membranes. In particular, HIV myrMA show more affinity for cholesterol-containing biomimetic membranes [57], and cholesterol enhances the binding specificity of HIV-MA to $\mathrm{PI}(4,5) \mathrm{P}_{2}$ [67], in accordance with the finding that retroviruses can bud in cholesterol-enriched membrane domains such as lipid rafts [74-76].

Surprisingly enough, another element, the RNA, was recently found to be involved in the regulation and the specificity of HIV-MA membrane binding [69]. Indeed, HIV-MA has long been known to bind RNA efficiently in vitro [67,70,77-79], as does BLV-MA [80] and RSVMA [81]. Moreover, HIV-MA specifically interacts with RNA, bearing a high degree of homology to a region within the Pol open reading frame of the HIV-1 genome, suggesting that the RNA molecule interacting with MA in cells might be the viral gRNA [79]. Interestingly, the basic residues of HIV-1 MA involved in the interaction with RNA are also necessary for $\mathrm{PI}(4,5) \mathrm{P}_{2}$ binding $[66,70,77,79]$. Thus, RNA might be a competitive inhibitor of the interaction with $\mathrm{PI}(4,5) \mathrm{P}_{2}$. As a matter of fact, Chukkapalli and colleagues observed that RNAse treatment increased binding of Gag to both neutral and acidic LUVs (PC, +/- PS, +/- PI $\left.(4,5) \mathrm{P}_{2}\right)$ [69]. The hypothesis is that RNA would inhibit the entropic switch, stabilizing the $[\mathrm{T}]$ conformation (Figure $3 \mathrm{Ab}$ ), thus preventing membrane-binding in general. On the other hand, Alfadhli and colleagues [67] simultaneously found that $\mathrm{PI}(4,5) \mathrm{P}_{2}$ is the only lipid that can remove nucleic acids bound to HIV-1 myrMA recombinant protein. This favors the idea that RNA would ensure the specificity of the interaction of MA with the $\operatorname{PI}(4,5) \mathrm{P}_{2}$, which therefore appears as a relevant cellular partner of Gag during the assembly process, allowing MA to switch from a "transport" [T] conformation to a "membrane binding" [R] conformation. RNA-meditated regulation of HIV-MA binding to $\mathrm{PI}(4,5) \mathrm{P}_{2}$ seems to be supported by the data emerging from in cellulo studies. A functional link between the genomic RNA exporting pathway and the HIV-1 MA-driven assembly has been established recently, even if the precise mechanism has not been elucidated [82-85]. Whether gRNA plays a role in MA/lipid interaction for other retroviruses is not known as yet. EIAV or MLV does not seem to have the same dependency on gRNA export pathway for proper assembly $[84,85]$ as compared to HIV-1. In contrast, RSV-MA is able to interact with both PS [54] and RNA [81]. The measured affinity for $\mathrm{PI}(4,5) \mathrm{P}_{2}$ was found to be low in the case of RSV MA alone [54], but given the results obtained with HIV-MA, further investigation could prove useful. Thus, from an evolutionary point of

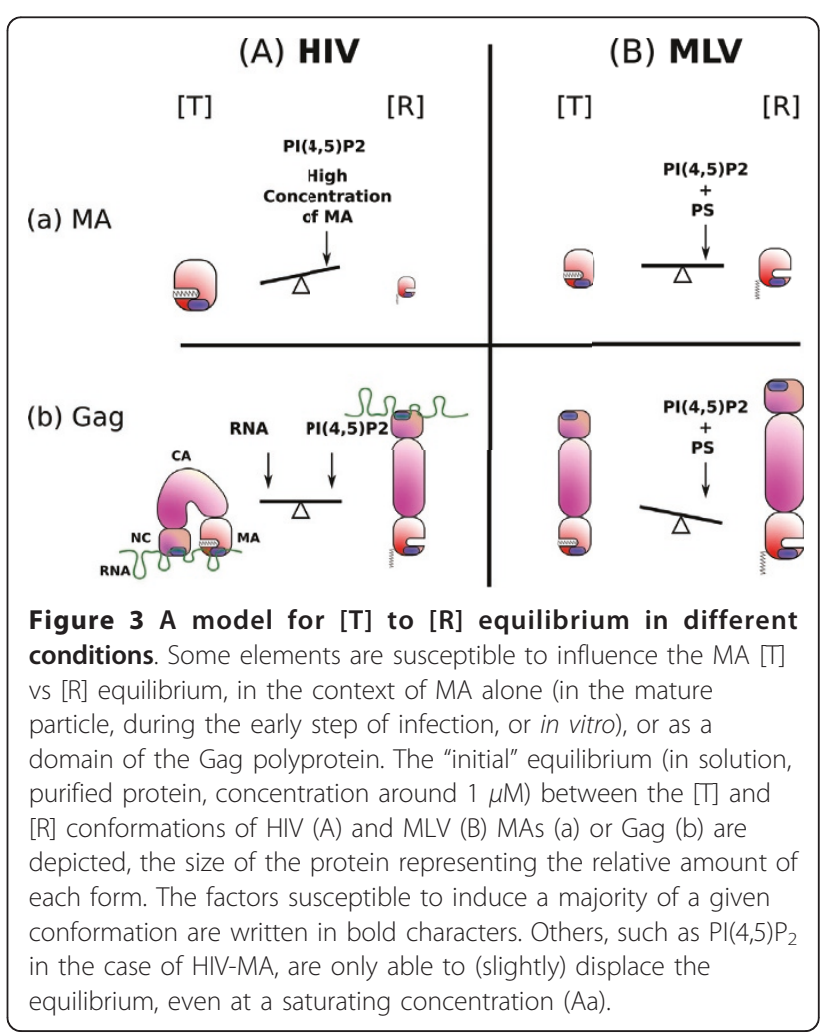


view, it would be interesting to determine if these regulation modes involving $\mathrm{PI}(4,5) \mathrm{P}_{2}$ and RNA are conserved among retroviruses, including those lacking MA myristylation.

In summary, we have proposed a model in which two different retroviral MAs use alternative mechanisms to bind membrane lipids, but end up with the same lipid specificity. MLV-MA is able to interact initially with PI $(4,5) \mathrm{P}_{2}$, and this interaction triggers a conformational modification that allows PS binding. In contrast, HIVMA would have initially low affinity for $\mathrm{PI}(4,5) \mathrm{P}_{2}$, especially in the presence of gRNA [69]. However, $\mathrm{PI}(4,5) \mathrm{P}_{2}$ seems to be the only compound able to compete with RNA for HIV-MA binding [67], and once RNA is removed, HIV-MA would be able to interact both with $\mathrm{PI}(4,5) \mathrm{P}_{2}$ and $\mathrm{PS}$, and this interaction may be stabilized by other elements, as discussed in the next section. Therefore, in spite of different lipid binding modes, the specificity of binding could be highly conserved among retroviruses.

\section{Let's switch again! Stabilization of the [R] conformation}

The interaction of retroviral MAs with $\mathrm{PI}(4,5) \mathrm{P}_{2}$ seems to be a conserved, highly specific, and regulated feature among retroviruses. As previously mentioned, $\mathrm{PI}(4,5) \mathrm{P}_{2}$ binding seems to be associated with conformational changes, as shown by NMR for HIV-1 MA [66] and EIAV-MA [86]. For HIV, it corresponds to the myr[s] and myr[e] conformations ([T] and [R] respectively) evidenced by structural studies [20], and it is probably also the case for EIAV except that it is not myristylated. This supports a pre-existing hypothesis first proposed by Zhou et al [31]: the existence of a "myristyl switch", that is actually an entropic equilibrium between the [T] conformation that sequesters the myristate inside the protein, and the $[R]$ conformation that promotes trimeristation and exposure of the myristate moiety allowing its insertion in the cellular membranes. A refinement of this model was proposed by Saad and colleagues, as the NMR data on HIV-MA suggested that the insertion of the myristate into the lipidic bilayer may be compensated by the extraction of the 2' fatty acid chain of the $\mathrm{PI}(4,5) \mathrm{P}_{2}$ out of the membrane, that would then be sequestrated into the hydrophobic core of the MA domain (Figure 4Ad) [66]. Anraku and colleagues compared the affinity of HIV-1 MA and Gag for phophorylated inositol ring alone and for medium length fatty acid chain lipids (Di-C8-PI $\left.(4,5) \mathrm{P}_{2}\right)$, in order to compare the relative contribution of electrostatic interactions (with inositol phosphate ring) and hydrophobic interactions (with acyl chains) [71]. In accordance with the data from Saad et al. [66], acyl chains were found to have a major contribution in the interaction. This model, however, is built on data obtained with short chain fatty acids, and needs further confirmation in lipid bilayer conditions.

As a model for HIV-MA/PI $(4,5) \mathrm{P}_{2}$ interaction, we propose that the $[\mathrm{T}]$ conformation has a high affinity for RNA, and a low affinity for $\mathrm{PI}(4,5) \mathrm{P}_{2}$. On the contrary, the $[R]$ conformation has a high affinity for $\mathrm{PI}(4,5) \mathrm{P}_{2}$. PI $(4,5) \mathrm{P}_{2}$ would compete with RNA for HIV-MA binding as recently proposed $[69,87]$ and its interaction with MA would in turn stabilize the [R] conformation as shown by Saad and colleagues [66] (Figure 3Aa). In this model, $\mathrm{PI}(4,5) \mathrm{P}_{2}$ has two roles: in addition to being the "substrate" (i.e. the bound molecule), it is also an effector, stabilizing the binding prone conformation, [R] (Figure $3 \mathrm{Aa})$. In other words, $\mathrm{PI}(4,5) \mathrm{P}_{2}$ is able to displace a pre-exiting equilibrium toward the $[\mathrm{R}]$ conformation, as suggested by Tang et al [20]. Symmetrically, RNA would have an "allosteric inhibitor" effect in stabilizing the [T] conformation (Figure 3Aa). This property may prevent a specific binding to membranes lacking $\mathrm{PI}(4,5) \mathrm{P}_{2}$. This model could explain why many authors were unable to measure the affinity of HIV-1 MA for $\mathrm{PI}(4,5) \mathrm{P}_{2}$ in the LUV system [42,55]. At low HIV-MA concentrations (from $1 \mu \mathrm{M}$ to $20 \mu \mathrm{M}$ ), the equilibrium would be only slightly displaced toward the $[\mathrm{R}]$ conformation, even at a saturating $\mathrm{PI}(4,5) \mathrm{P}_{2}$ concentration (Figure $3 \mathrm{Aa}[42,54]$ ). The $[\mathrm{T}]$ conformation had very low affinity for the lipid; we and others concluded that the affinity of MA for PI $(4,5) \mathrm{P}_{2}$ was negligible in these conditions $[42,55]$. Many other elements could also influence the $[\mathrm{T}]$ to $[\mathrm{R}]$ equilibrium in vivo, to allow specific interaction of Gag with membranes. As mentioned earlier, a high concentration of MA promotes trimerization, and at the same time stabilizes the [R] conformation [20] (cf. Figure 3Aa). In addition, multimerization of Gag seems to correlate with the appearance of the $[R]$ state, as multimerizing regions in CA promote myristate exposure [20] and increase lipid binding of MA-CA constructs [55]in vitro. In cells, it has been shown that proteolytic cleavage of Gag induces partial dissociation of p17MA from the membrane, confirming that uncleaved Gag stabilizes the [R] conformation of MA $[31,88,89]$. Another parameter that seems to influence the $[\mathrm{T}]$ to $[\mathrm{R}]$ transition is $\mathrm{pH}$, as shown recently by Fledderman et al. [90]. High pH stabilizes the [T] form, while acidification favors myristate exposure. In addition, the same laboratory also reported that Calmodulin (CalN), a $\mathrm{Ca}^{2+}$ sensor protein determinant that interacts with HIV MA, promotes the myristyl switch [91].

The equilibrium constant between the $[\mathrm{T}]$ and $[\mathrm{R}]$ conformations also seems to vary greatly from one MA to another. As a matter of fact, in NMR conditions (high MA concentration, around $0.5 \mathrm{mM}$ ), HIV-1 and HIV-2 MAs behave differently in the presence of $\mathrm{PI}(4,5) \mathrm{P}_{2}$, the 


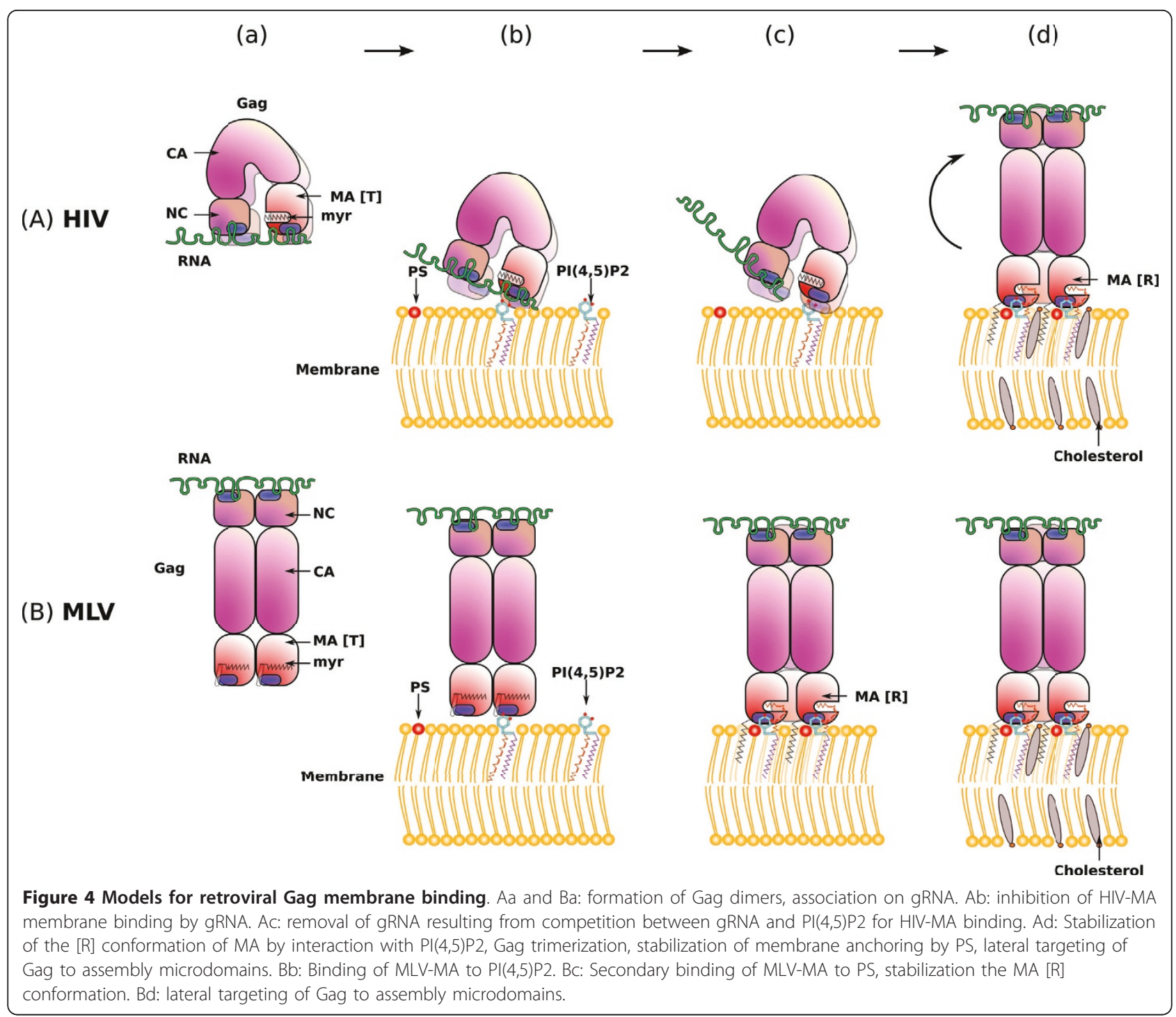

[R] conformation remains undetectable for HIV-2 MA [21], unlike HIV-1 [66]. As far as other viruses are concerned, less data are available. It is possible that $\mathrm{PI}(4,5) \mathrm{P}_{2}$ also stabilizes an [R] conformation of EIAV-MA as suggested by 2-D NMR data obtained by Chen et al [86], showing a slight amino acid shift upon $\mathrm{PI}(4,5) \mathrm{P}_{2}$ binding. In contrast, MLV MA may display a more complex behavior. We were able to calculate two Kd values for MA/PI $(4,5) \mathrm{P}_{2}$ interaction, either in the presence or absence of PS. The $[\mathrm{T}]$ conformation might be able to bind $\mathrm{PI}(4,5) \mathrm{P}_{2}$ with a $\mathrm{Kd}$ of $25 \mu \mathrm{M}$, while the [R] conformation might be stabilized by the presence of PS, allowing $\mathrm{PI}(4,5) \mathrm{P}_{2}$ to switch to the extended lipid conformation, with a resulting $\mathrm{Kd}$ value approaching $5 \mu \mathrm{M}$ (Figure 3Ba) [42]. Another hypothesis is that the majority of MA is already in the $[R]$ conformation, and that PS modulates the affinity of the interaction with $\mathrm{PI}(4,5) \mathrm{P}_{2}$.
The switch from the [T] to the [R] conformation may have further implications at the level of the entire Gag protein, thus influencing the assembly process. Indeed, Datta et al. recently proposed a model in which HIVGag would be in a bent conformation in solution, with $\mathrm{MA}$ and NC in close proximity [92,93] (Figure 3Ab). This model is supported by the fact that both NC and MA can bind IP6 (an inositol ring containing six phosphorylations, thus somewhat homologous to $\left.\mathrm{PI}(4,5) \mathrm{P}_{2}\right)$ in vitro, and is consistent with hydrodynamic and smallangle neutron scattering data. This is also in agreement with the idea that RNA can bind both NC and MA $[67,70,77-79]$. This is not compatible, however, with the immature particle organization, in which Gag is in an extended rod-shaped conformation [94]. Consequently, the authors propose that viral assembly is coupled with major conformational modifications of Gag (Figure 
$3 \mathrm{Ab})$. The same group showed that correct in vitro assembly of viral like particles necessitates both RNA and IP6 (that can be considered as an analog of PI $(4,5)$ $\mathrm{P}_{2}$ ). It is still the case when the NC domain is replaced by a multimerization domain such as a leucine zipper, suggesting that RNA not only plays a role in assembly via its interaction with the NC domain, but probably also at the level of the MA domain [95].

The ability of HIV-Gag to auto-assemble into viral-like particles in vitro seems to be linked with a switch from Gag dimers to Gag trimers that can be mediated by IP6 $[93,95]$. As it has been shown that $\mathrm{PI}(4,5) \mathrm{P}_{2}$ promotes HIV-MA trimeric association [87], the effect of IP6 addition could mimic the effect of $\mathrm{PI}(4,5) \mathrm{P}_{2}$ binding in cells, in stabilizing the $[R]$ conformation and promoting the formation of MA trimers. This could further trigger Gag structural reorganization via dimer to trimer transition (Figure 4Ad). A similar mechanism could drive the assembly of all retroviruses, as other retroviral MAs have multimerization properties upon $\mathrm{PI}(4,5) \mathrm{P}_{2}$ binding. For exemple, MLV-MA multimerizes in the presence of $\mathrm{PI}(4,5) \mathrm{P}_{2}$ under certain conditions (unpublished personal data), and EIAV-MA forms trimers [32].

MLV-Gag, however, seems to differ in some points from lentiviral Gag proteins. Datta et al. showed that in vitro recombinant MLV-Gag is readily in a rodshaped conformation in solution, with a much more rigid structure (Datta, Zuo, Campbell, Wang, Rein: Personnal communication) (Figure $3 \mathrm{Bb}$ ). This property might argue for an absence of an RNA mediated maintenance of the [T] conformation for MLV-MA. This correlates with the fact that the $[R]$ conformation of MLV-MA appears more stable, as 100\% of MLV-Gag is associated with membranes in cells [42], in contrast with HIV-Gag which is no more than $60 \%$ membrane bound [96]. However, we cannot exclude the possibility that RNA could regulate the interaction of MLV-MA with lipids.

The mechanisms of interaction between retroviral MAs and lipids are quite original, and whether some particularities of these binding modes can also apply to other viral or cellular proteins is not known. For instance, other retroviral proteins could interact with lipids using a similar mechanism. For example, Nef and Tat, two regulatory proteins of HIV, also bind membranes. In fact, Nef is a myristylated protein able to bind acidic phospholipids, but the curvature of the membrane induced upon Nef binding is not consistent with the extraction of a fatty acid out of the membrane [97] as in the model proposed for HIV-MA [66]. A myristyl switch mechanism is still possible, however, as the binding of Nef to biomimetic membranes is a biphasic process, with a first phase of electrostatic interaction with acidic phospholipids, and a second phase of structural modifications (in particular, the formation of an amphiphatic helix) [97]. As for Tat, it was recently shown that it also interacts with $\mathrm{PI}(4,5) \mathrm{P}_{2}$ before crossing the plasma membrane and being secreted into the extracellular environment [98-100].

\section{Conclusion: Cellular consequence of Gag binding to $\mathrm{PI}(4,5) \mathrm{P}_{2}$ and $\mathrm{PS}$}

Taking all the previously discussed data together allowed us to propose a model for the role played by MA during HIV and MLV assembly initiation, at the molecular level (Figure 4). In this model, Gag first polymerizes on gRNA ( $\mathrm{Aa}$ and $\mathrm{Ba}$ ), but adopts a bent conformation in the case of HIV (Aa), with both MA and NC interacting with gRNA, while MLV-Gag is readily in a rod-shaped conformation $(\mathrm{Ba})$. For both viruses, the [T] conformation of MA is initially dominant, with myristate trapped in the protein core. When HIV-MA reaches $\mathrm{PM}(\mathrm{Ab}), \mathrm{PI}(4,5) \mathrm{P}_{2}$ is able to compete with gRNA for MA binding (Ac). Removal of gRNA and interaction with $\mathrm{PI}(4,5) \mathrm{P}_{2}$ stabilize the $[\mathrm{R}]$ conformation of MA (exposed myristate), which in turn promotes the trimerization and the reorganization of Gag into its rodshapped conformation (Ad). The presence of PS could stabilize the interaction between MA and $\mathrm{PI}(4,5) \mathrm{P}_{2}$ (Ad). Gag would then be laterally targeted to membrane microdomains containing high levels of saturated lipids, such as lipid rafts (Ad). In the case of MLV, initial binding to $\mathrm{PI}(4,5) \mathrm{P}_{2}(\mathrm{Bb})$ is followed by a secondary binding to PS $(\mathrm{Bc})$ that would further stabilize the $[\mathrm{R}]$ conformation of MA, exposing the myristate. Like HIV, lateral targeting of Gag to rafts or other microdomains is likely to occur afterwards (Bd).

These mechanistic observations are useful to re-evaluate the data available regarding assembly and budding localization in cells. Analysis of the retroviral particle envelope content evidenced that budding membranes resemble the plasma membrane in terms of lipid composition [73,75,101-105]. The ratio between lipids, however, differs from the average plasma membrane composition. In particular, viral particles of HIV and MLV are enriched not only in PI $(4,5) \mathrm{P}_{2}$ and PS, but also in cholesterol, ceramides, GM3 and sphingolipids [73]. This can reflect the fact that viral particles are produced in specific membrane microdomains. Moreover, HIV virions are also enriched in lipid raft markers such as GPI-anchored proteins [106], actin and actin-associated proteins, such as Ezrin-Radixin-Moesin proteins (ERMs) [107,108], and in tetraspanins [108-116]. ERM and tetraspanins are also found in particles of MLV $[107,117,118]$. In consequence, retroviral budding has been proposed to occur preferentially in two types of membrane microdomains associated with actin cytoskeleton: lipid rafts and tetraspanin enriched microdomains (TEMs). There is a spatial and functional distinction, however, between these two kind 
of domains [119-121], even if they are adjacent and may interact [122-124].

Lipid rafts are membrane domains enriched in cholesterol and sphingolipids, but can also be enriched in PI $(4,5) \mathrm{P}_{2}$ and PS under specific conditions [125-128]. Rafts were initially identified as detergent-resistant membranes, and this property was widely utilized to characterize raft-associated lipids and proteins, including HIV-Gag [74,129-137], MLV-Gag [76,136] and HTLV-1-Gag $[136,138]$. The existence in living cell, the exact nature, and the actual size of lipid rafts has, however, been intensely debated over the past decades. The current consensus is that lipid rafts are nanoscale concentrations of specific lipids, notably cholesterol and sphingolipids, and proteins (reviewed in $[128,139]$ ). Their size is around 10 to $20 \mathrm{~nm}$ but they can coalesce and organize membrane bioactivity in many ways.

The association of HIV-Gag with lipid rafts depends on both membrane association signals of MA, the myristate and the HBR (reviewed in [140,141]). Lower order multimerization is also necessary because the association of CA mutants with lipid rafts is delayed [74], however, higher order association appears to be dispensable as demonstrated by NC mutants [142]. Lipid raft targeting is a slower process than membrane association, giving the idea that initial docking of Gag at the plasma membrane is followed by lateral transport to assembly microdomains as proposed by Ono and Freed [74].

Saad and colleagues [66] proposed a very elegant model in agreement with a preferential budding of HIV in raft microdomains. Their NMR data suggests that the 2'-fatty acid of the $\operatorname{PI}(4,5) \mathrm{P}_{2}$ is extracted from the membrane bilayer upon MA binding, and sequestrated inside the protein, in the same hydrophobic pocket the myristate occupied. Unlike the 2'-chain, the 1'-chain is usually saturated, as is the myristate (cf. Figure 4). If this model proves to be correct, Gag would then be anchored to the membrane via two saturated chains (myristate and 1 '-chain) and this could result in a lateral targeting of Gag to lipid rafts, where saturated lipids are enriched (Figure 4d, Bd).

The trapping of $\mathrm{PI}(4,5) \mathrm{P}_{2}$ into lipid rafts by Gag may have important consequences in terms of cellular responses. Indeed, in non-infected cells, it seems that the ratio of raft-associated $\mathrm{PI}(4,5) \mathrm{P}_{2}$ versus raft-excluded $\mathrm{PI}(4,5) \mathrm{P}_{2}$ is finely regulated. Any modification of one pool seems to have profound consequences, in particular on cytoskeleton remodelling, cell morphology and modulation of signaling pathways, such as the PI3K-Akt pathway [143].

Whether Gag, and in particular the MA domain, is able to aggregate lipid raft microdomains (directly or indirectly) or bind to pre-formed platforms is not as yet known, even if recent findings argue for dynamic aggregation of raft components by Gag [116]. Annexin 2 could potentially play a role, as this protein interacts with Gag $[108,144]$ and is able to aggregate lipids, in particular cholesterol, PS, and $\mathrm{PI}(4,5) \mathrm{P}_{2}[145,146]$. Other viral proteins may be involved too. It was recently shown that $g P r 80^{[g a g]}$, a long glycosylated form of MLVGag, increases the release of MLV and HIV particles via lipid rafts [76]. A similar role has been observed for HIV-Nef [147], which also increases the "raft-like" properties of HIV particles [105] and modifies the cholesterol metabolism of producer cells [148]. However, it is not known how these two proteins act to relocate assembly in these microdomains.

On the other hand, several authors have reported that retroviral assembly occurs in association with tetraspanins [108-116,149-151]. Some tetraspanins can modulate viral infectivity and regulate cell to cell transmission [115], while the role of others, such as CD63, is currently debated [152]. The tetraspanins are a family of small transmembrane proteins that operate as major lateral organizers of membrane domains. They form tetraspanin-enriched microdomains (TEMs) or tetraspanin webs, in close relation with the cytoskeleton (reviewed in [153]). TEMs are enriched in cholesterol, GM1 and sphingolipids, but only a small fraction of the tetraspanins are found in the detergent resistant membrane (DRM) fractions, unlike raft proteins. Some tetraspanins, including CD9, CD63, CD81, and CD51 are associated with PI4K, a kinase that allows the synthesis of PI(4)P, the main precurssor of $\mathrm{PI}(4,5) \mathrm{P}_{2}$. In particular, HIV-Gag seems to associate specifically with CD63 and CD81 and less with CD82 [108,109,113-115] while HTLV-1 Gag associates preferentially with CD82 at the plasma membrane [149-151]. It is noteworthy that CD82 does not associate with PI4K and that this may be related to the unusual particle production mode of HTLV, with preferential budding at the cell-to-cell contact areas and low production of cell-free virions. One unresolved question is whether there is a collaboration between rafts and TEMs during particle assembly or whether distinct budding microdomains exist in the cell. In support of the first hypothesis, it was observed that some tetraspanins are able to address protein complexes toward lipid rafts, inducing the activation of specific signalization pathways. In particular, $\mathrm{CD} 81$ is necessary to partition the $\mathrm{B}$ cell receptor (BCR) and the CD19/CD21/CD81 complex into rafts $[122,123]$, while CD82 links the actin cytoskeleton, $\mathrm{T}$ cell receptors and raft domains [124]. This suggests that tetraspanins may help to target Gag to lipid rafts, or, the other way around, that Gag could recruit tetraspanins and lipid raft components in order to activate particular signalization pathways necessary for sustaining HIV infection. This later model is supported by recent work by Krementsov et al. showing the strong trapping of 
CD9 and the transient trapping of cholesterol, GM1 and CD55 into the HIV-1 assembly microdomains [116]. Interaction between TEMs and lipid rafts could result in the activation of TCR signalization pathway from which HIV could benefit. This pathway comprises, for example, the protein Lck, a Src-kinase participating in T-cell activation [154], that interacts with HIV-Gag and increases particle production [155]. Moreover, the activation of TCR not only causes the accumulation of raft lipids in the membrane areas involved in the TCR signaling pathway but also recruits PS, which is probably necessary for Gag stabilization in PM microdomains during particle formation [127].

The enriched literature on retroviral assembly has allowed us to postulate a quite precise model of the molecular events that drive the anchoring of Gag to cellular membranes preceding particle formation, but these models remain to be tested experimentally. The high conservation of the overall process is striking, especially concerning the specificity of the interaction between Matrix domain of Gag and cellular lipids (PI(4,5)P2, PS, cholesterol), and suggests that targeting retroviral assembly by therapeutical approaches may be a good strategy to combat HIV infection.

\section{Acknowledgements}

We especially want to thank Dr Robin Buckland for his critical reading of the manuscript. This work was supported by INSERM and CNRS. EHP is a fellowship receiver of the French Government.

\section{Authors' contributions}

EH wrote the manuscript and made the figures. DM contributed to the manuscript writing and editing. All authors read and approved the final manuscript.

\section{Competing interests}

The authors declare that they have no competing interests.

Received: 29 October 2010 Accepted: 7 March 2011

Published: 7 March 2011

\section{References}

1. Adamson CS, Jones IM: The molecular basis of HIV capsid assembly-five years of progress. Rev Med Virol 2004, 14(2):107-21.

2. Darlix JL, Lapadat-Tapolsky M, de Rocquigny H, Roques BP: First glimpses at structure-function relationships of the nucleocapsid protein of retroviruses. J Mol Biol 1995, 254(4):523-37.

3. Rein A: Retroviral RNA packaging: a review. Arch Virol Supp/ 1994, 9:513-22.

4. Jouvenet N, Simon SM, Bieniasz PD: Imaging the interaction of HIV-1 genomes and Gag during assembly of individual viral particles. Proc Natl Acad Sci USA 2009, 106(45):19114-9.

5. Ott DE, Coren LV, Shatzer T: The nucleocapsid region of human immunodeficiency virus type $1 \mathrm{Gag}$ assists in the coordination of assembly and Gag processing: role for RNA-Gag binding in the early stages of assembly. J Virol 2009, 83(15):7718-27.

6. Delelis O, Lehmann-Che J, Saïb A: Foamy viruses-a world apart. Curr Opin Microbiol 2004, 7(4):400-6.

7. Choi G, Park S, Choi B, Hong S, Lee J, Hunter E, Rhee SS: Identification of a cytoplasmic targeting/retention signal in a retroviral Gag polyprotein. J Virol 1999, 73(7):5431-7.
8. Parent $L$, Wilson $C B$, Resh MD, Wills JW: Evidence for a second function of the MA sequence in the Rous sarcoma virus Gag protein. J Virol 1996, 70(2):1016-26[http://view.ncbi.nlm.nih.gov/pubmed/8551559].

9. Reed M, Mariani R, Sheppard L, Pekrun K, Landau NR, Soong NW: Chimeric human immunodeficiency virus type 1 containing murine leukemia virus matrix assembles in murine cells. J Virol 2002, 76:436-43.

10. Chen BK, Rousso I, Shim S, Kim PS: Efficient assembly of an HIV-1/MLV Gag-chimeric virus in murine cells. Proc Natl Acad Sci USA 2001, 98(26):15239-44

11. Manrique ML, Gonzalez SA, Affranchino JL: Functional relationship between the matrix proteins of feline and simian immunodeficiency viruses. Virology 2004, 329:157-67.

12. Veronese FD, Copeland TD, Oroszlan S, Gallo RC, Sarngadharan MG: Biochemical and immunological analysis of human immunodeficiency virus gag gene products p17 and p24. J Virol 1988, 62(3):795-801.

13. Ootsuyama Y, Shimotohno K, Miwa M, Oroszlan S, Sugimura T: Myristylation of gag protein in human T-cell leukemia virus type-I and type-II. Jpn J Cancer Res 1985, 76(12):1132-5.

14. Schultz AM, Oroszlan S: In vivo modification of retroviral gag geneencoded polyproteins by myristic acid. J Virol 1983, 46(2):355-61.

15. Henderson LE, Krutzsch HC, Oroszlan S: Myristyl amino-terminal acylation of murine retrovirus proteins: an unusual post-translational proteins modification. Proc Natl Acad Sci USA 1983, 80(2):339-43.

16. Rein A, McClure MR, Rice NR, Luftig RB, Schultz AM: Myristylation site in Pr65gag is essential for virus particle formation by Moloney murine leukemia virus. Proc Natl Acad Sci USA 1986, 83(19):7246-50.

17. Massiah MA, Starich MR, Paschall C, Summers MF, Christensen AM, Sundquist Wl: Three-dimensional structure of the human immunodeficiency virus type 1 matrix protein. J Mol Biol 1994, 244(2):198-223.

18. Matthews S, Barlow P, Boyd J, Barton G, Russell R, Mills $H$, Cunningham M, Meyers N, Burns N, Clark N, et al: Structural similarity between the p17 matrix protein of HIV-1 and interferon-gamma. Nature 1994, 370(6491):666-8.

19. Hill CP, Worthylake D, Bancroft DP, Christensen AM, Sundquist WI: Crystal structures of the trimeric human immunodeficiency virus type 1 matrix protein: implications for membrane association and assembly. Proc Nat Acad Sci USA 1996, 93(7):3099-104.

20. Tang C, Loeliger E, Luncsford P, Kinde I, Beckett D, Summers MF: Entropic switch regulates myristate exposure in the HIV-1 matrix protein. ProC Natl Acad Sci USA 2004, 101(2):517-22

21. Saad JS, Ablan SD, Ghanam RH, Kim A, Andrews K, Nagashima K, Soheilian F, Freed EO, Summers MF: Structure of the myristylated human immunodeficiency virus type 2 matrix protein and the role of phosphatidylinositol-(4,5)-bisphosphate in membrane targeting. J Mol Biol 2008, 382(2):434-47.

22. Rao Z, Belyaev AS, Fry E, Roy P, Jones IM, Stuart DI: Crystal structure of SIV matrix antigen and implications for virus assembly. Nature 1995, 378(6558):743-7.

23. Christensen AM, Massiah MA, Turner BG, Sundquist WI, Summers MF: Three-dimensional structure of the HTLV-II matrix protein and comparative analysis of matrix proteins from the different classes of pathogenic human retroviruses. J Mol Biol 1996, 264(5):1117-31, [Plein de refs pour trucs de base: basic residues, myr, etc HTLV-II: 4 helices alpha, une "3-10" (helice courte) patch basique]..

24. Matthews S, Mikhailov M, Burny A, Roy P: The solution structure of the bovine leukaemia virus matrix protein and similarity with lentiviral matrix proteins. EMBO J 1996, 15(13):3267-74.

25. Conte MR, Klikova M, Hunter E, Ruml T, Matthews S: The three-dimensional solution structure of the matrix protein from the type $D$ retrovirus, the Mason-Pizer monkey virus, and implications for the morphology of retroviral assembly. EMBO J 1997, 16(19):5819-26.

26. McDonnell JM, Fushman D, Cahill SM, Zhou W, Wolven A, Wilson CB, Nelle TD, Resh MD, Wills J, Cowburn D: Solution structure and dynamics of the bioactive retroviral $\mathrm{M}$ domain from Rous sarcoma virus. $J \mathrm{Mol} \mathrm{BiO} /$ 1998, 279(4):921-8[http://view.ncbi.nlm.nih.gov/pubmed/9642071].

27. Hatanaka H, lourin O, Rao Z, Fry E, Kingsman A, Stuart DI: Structure of equine infectious anemia virus matrix protein. J Virol 2002, 76(4):1876-83.

28. Riffel N, Harlos K, lourin O, Rao Z, Kingsman A, Stuart D, Fry E: Atomic resolution structure of Moloney murine leukemia virus matrix protein 
and its relationship to other retroviral matrix proteins. Structure 2002, 10(12):1627-36.

29. Conte MR, Matthews S: Retroviral matrix proteins: a structural perspective. Virology 1998, 246(2):191-8.

30. Murray PS, Li Z, Wang J, Tang CL, Honig B, Murray D: Retroviral matrix domains share electrostatic homology: models for membrane binding function throughout the viral life cycle. Structure 2005, 13(10):1521-31.

31. Zhou W, Resh MD: Differential membrane binding of the human immunodeficiency virus type 1 matrix protein. J Virol 1996, 70(12):8540-8.

32. Chen K, Bachtiar I, Piszczek G, Bouamr F, Carter C, Tjandra N: Solution NMR characterizations of oligomerization and dynamics of equine infectious anemia virus matrix protein and its interaction with PIP2. Biochemistry 2008, 47(7):1928-37.

33. Paillart JC, Gottlinger HG: Opposing effects of human immunodeficiency virus type 1 matrix mutations support a myristyl switch model of gag membrane targeting. J Virol 1999, 73(4):2604-12.

34. Saad JS, Loeliger E, Luncsford P, Liriano M, Tai J, Kim A, Miller J, Joshi A, Freed EO, Summers MF: Point mutations in the HIV-1 matrix protein turn off the myristyl switch. J Mol Biol 2007, 366(2):574-85.

35. Hansen M, Jelinek L, Whiting S, Barklis E: Transport and assembly of gag proteins into Moloney murine leukemia virus. J Virol 1990, 64(11):5306-16.

36. Bryant M, Ratner L: Myristoylation-dependent replication and assembly of human immunodeficiency virus 1. Proc Natl Acad Sci USA 1990, 87(2):523-7.

37. Rhee SS, Hunter E: Myristylation is required for intracellular transport but not for assembly of D-type retrovirus capsids. J Virol 1987, 61(4):1045-53.

38. Yuan $X, Y u X$, Lee TH, Essex M: Mutations in the N-terminal region of human immunodeficiency virus type 1 matrix protein block intracellular transport of the Gag precursor. J Virol 1993, 67(11):6387-94.

39. Freed EO, Englund G, Martin MA: Role of the basic domain of human immunodeficiency virus type 1 matrix in macrophage infection. J Virol 1995, 69(6):3949-54

40. Ono A, Orenstein JM, Freed EO: Role of the Gag matrix domain in targeting human immunodeficiency virus type 1 assembly. J Virol 2000, 74(6):2855-66.

41. Zhou W, Parent LJ, Wills JW, Resh MD: Identification of a membranebinding domain within the amino-terminal region of human immunodeficiency virus type $1 \mathrm{Gag}$ protein which interacts with acidic phospholipids. J Virol 1994, 68(4):2556-69.

42. Hamard-Peron E, Juillard F, Saad JS, Roy C, Roingeard P, Summers MF, Darlix UL, Picart C, Muriaux D: Targeting of murine leukemia virus gag to the plasma membrane is mediated by $\mathrm{PI}(4,5) \mathrm{P} 2 / \mathrm{PS}$ and a polybasic region in the matrix. J Virol 2010, 84:503-15.

43. Soneoka Y, Kingsman SM, Kingsman AJ: Mutagenesis analysis of the murine leukemia virus matrix protein: identification of regions important for membrane localization and intracellular transport. J Virol 1997, 71(7):5549-59.

44. Manrique ML, Celma CC, Gonzalez SA, Affranchino JL: Mutational analysis of the feline immunodeficiency virus matrix protein. Virus Res 2001, 76:103-13.

45. Callahan EM, Wills JW: Repositioning basic residues in the M domain of the Rous sarcoma virus gag protein. J Virol 2000, 74(23):11222-9.

46. Le Blanc I, Rosenberg AR, Dokhelar MC: Multiple functions for the basic amino acids of the human T-cell leukemia virus type 1 matrix protein in viral transmission. J Virol 1999, 73(3):1860-7.

47. Stansell E, Apkarian R, Haubova S, Diehl WE, Tytler EM, Hunter E: Basic residues in the Mason-Pfizer monkey virus gag matrix domain regulate intracellular trafficking and capsid-membrane interactions. J Virol 2007, 81(17):8977-88.

48. Hoxie JA, Haggarty BS, Rackowski JL, Pillsbury N, Levy JA: Persistent noncytopathic infection of normal human T lymphocytes with AIDSassociated retrovirus. Science 1985, 229(4720):1400-2.

49. Suomalainen M, Hultenby K, Garoff H: Targeting of Moloney murine leukemia virus gag precursor to the site of virus budding. I Cell Biol 1996, $135(6$ Pt 2):1841-52.

50. Benaroch P, Billard E, Gaudin R, Schindler M, Jouve M: HIV-1 assembly in macrophages. Retrovirology 2010, 7:29.

51. Corbin A, Grigorov B, Roingeard P, Darlix JL, Muriaux D: [Revisiting HIV-1 assembly]. Med Sci (Paris) 2008, 24:49-55.

52. van Meer G, Voelker DR, Feigenson GW: Membrane lipids: where they are and how they behave. Nat Rev Mol Cell Biol 2008, 9(2):112-24.
53. Cho W, Bittova L, Stahelin RV: Membrane binding assays for peripheral proteins. Anal Biochem 2001, 296(2):153-61.

54. Dalton AK, Murray PS, Murray D, Vogt VM: Biochemical characterization of rous sarcoma virus MA protein interaction with membranes. J Virol 2005, 79(10):6227-38.

55. Dalton AK, Ako-Adjei D, Murray PS, Murray D, Vogt VM: Electrostatic interactions drive membrane association of the human immunodeficiency virus type 1 Gag MA domain. J Virol 2007, 81(12):6434-45.

56. Ehrlich LS, Fong S, Scarlata S, Zybarth G, Carter C: Partitioning of HIV-1 Gag and Gag-related proteins to membranes. Biochemistry 1996, 35:3933-3943.

57. Provitera P, El-Maghrabi R, Scarlata S: The effect of HIV-1 Gag myristoylation on membrane binding. Biophys Chem 2006, 119:23-32.

58. Barrera FN, Hurtado-Gomez E, Lidon-Moya MC, Neira JL: Binding of the Cterminal domain of the HIV-1 capsid protein to lipid membranes: a biophysical characterization. Biochem J 2006, 394(Pt 1):345-53.

59. Barrera FN, del Alamo M, Mateu MG, Neira JL: Envelope lipids regulate the in vitro assembly of the HIV-1 capsid. Biophys J 2008, 94(2):L8-10.

60. Provitera P, Bouamr F, Murray D, Carter C, Scarlata S: Binding of equine infectious anemia virus matrix protein to membrane bilayers involves multiple interactions. J Mol Biol 2000, 296:887-898.

61. Ono A, Ablan SD, Lockett SJ, Nagashima K, Freed EO: Phosphatidylinositol $(4,5)$ bisphosphate regulates HIV-1 Gag targeting to the plasma membrane. Proc Natl Acad Sci USA 2004, 101(41):14889-94.

62. Chan WT, Sherer NM, Uchil PD, Novak EK, Swank RT, Mothes W: Murine leukemia virus spreading in mice impaired in the biogenesis of secretory lysosomes and Ca2+-regulated exocytosis. PLOS ONE 2008, 3(7): e2713.

63. Di Paolo G, De Camilli P: Phosphoinositides in cell regulation and membrane dynamics. Nature 2006, 443(7112):651-7.

64. Krauss M, Haucke V: Phosphoinositides: regulators of membrane traffic and protein function. FEBS Lett 2007, 581(11):2105-11.

65. Krauss $M$, Haucke $V$ : Phosphoinositide-metabolizing enzymes at the interface between membrane traffic and cell signalling. EMBO Rep 2007, 8(3):241-6.

66. Saad JS, Miller J, Tai J, Kim A, Ghanam RH, Summers MF: Structural basis for targeting HIV-1 Gag proteins to the plasma membrane for virus assembly. Proc Natl Acad Sci USA 2006, 103(30):11364-9.

67. Alfadhli A, Still A, Barklis E: Analysis of human immunodeficiency virus type 1 matrix binding to membranes and nucleic acids. J Virol 2009, 83(23):12196-203.

68. Chukkapalli V, Hogue IB, Boyko V, Hu WS, Ono A: Interaction between the human immunodeficiency virus type $1 \mathrm{Gag}$ matrix domain and phosphatidylinositol-(4,5)-bisphosphate is essential for efficient gag membrane binding. J Virol 2008, 82(5):2405-17.

69. Chukkapalli V, Oh SJ, Ono A: Opposing mechanisms involving RNA and lipids regulate HIV-1 Gag membrane binding through the highly basic region of the matrix domain. Proc Natl Acad Sci USA 2010.

70. Shkriabai N, Datta SAK, Zhao Z, Hess S, Rein A, Kvaratskhelia M: Interactions of HIV-1 Gag with assembly cofactors. Biochemistry 2006, 45(13):4077-83.

71. Anraku K, Fukuda R, Takamune N, Misumi S, Okamoto Y, Otsuka M, Fujita M: Highly sensitive analysis of the interaction between HIV-1 Gag and phosphoinositide derivatives based on surface plasmon resonance. Biochemistry 2010, 49(25):5109-16.

72. Valentine KG, Peterson RW, Saad JS, Summers MF, Xu X, Ames JB, Wand AJ: Reverse Micelle Encapsulation of Membrane-Anchored Proteins for Solution NMR Studies. Structure 2010, 18:9-16.

73. Chan R, Uchil PD, Jin J, Shui G, Ott DE, Mothes W, Wenk MR: Retroviruses human immunodeficiency virus and murine leukemia virus are enriched in phosphoinositides. J Virol 2008, 82(22):11228-38[http://view.ncbinlm.nih. gov/pubmed/18799574].

74. Ono A, Freed EO: Plasma membrane rafts play a critical role in HIV-1 assembly and release. Proc Natl Acad Sci USA 2001, 98(24):13925-30.

75. Brugger B, Glass B, Haberkant P, Leibrecht I, Wieland FT, Krausslich HG: The HIV lipidome: a raft with an unusual composition. Proc Natl Acad Sci USA 2006, 103(8):2641-6.

76. Nitta T, Kuznetsov Y, McPherson A, Fan H: Murine leukemia virus glycosylated Gag (gPr80gag) facilitates interferon-sensitive virus release through lipid rafts. Proc Natl Acad Sci USA 2010, 107(3):1190-5. 
77. Cimarelli A, Luban J: Translation elongation factor 1-alpha interacts specifically with the human immunodeficiency virus type $1 \mathrm{Gag}$ polyprotein. J Virol 1999, 73(7):5388-401, [Montre que MA interagit avec facteur+ARN].

78. Lochrie MA, Waugh S, Pratt DGJ, Clever J, Parslow TG, Polisky B: In vitro selection of RNAs that bind to the human immunodeficiency virus type1 gag polyprotein. Nucleic Acids Res 1997, 25(14):2902-10.

79. Purohit P, Dupont S, Stevenson M, Green MR: Sequence-specific interaction between HIV-1 matrix protein and viral genomic RNA revealed by in vitro genetic selection. RNA 2001, 7(4):576-84.

80. Wang H, Norris KM, Mansky LM: Involvement of the matrix and nucleocapsid domains of the bovine leukemia virus Gag polyprotein precursor in viral RNA packaging. J Virol 2003, 77(17):9431-8.

81. Parent LJ, Cairns TM, Albert JA, Wilson CB, Wills JW, Craven RC: RNA dimerization defect in a Rous sarcoma virus matrix mutant. J Virol 2000 74:164-72.

82. Sherer NM, Swanson CM, Papaioannou S, Malim MH: Matrix mediates the functional link between human immunodeficiency virus type 1 RNA nuclear export elements and the assembly competency of Gag in murine cells. J Virol 2009, 83(17):8525-35.

83. Hubner W, Chen BK: Inhibition of viral assembly in murine cells by HIV-1 matrix. Virology 2006, 352:27-38.

84. Jin J, Sturgeon T, Chen C, Watkins SC, Weisz OA, Montelaro RC: Distinct intracellular trafficking of equine infectious anemia virus and human immunodeficiency virus type $1 \mathrm{Gag}$ during viral assembly and budding revealed by bimolecular fluorescence complementation assays. J Virol 2007, 81(20):11226-35.

85. Jin J, Sturgeon T, Weisz OA, Mothes W, Montelaro RC: HIV-1 matrix dependent membrane targeting is regulated by Gag mRNA tracking. PLoS One 2009, 4(8):e6551.

86. Chen C, Jin J, Rubin M, Huang L, Sturgeon T, Weixel KM, Stolz DB, Watkins SC, Bamburg JR, Weisz OA, Montelaro RC: Association of gag multimers with filamentous actin during equine infectious anemia virus assembly. Curr HIV Res 2007, 5(3):315-23.

87. Alfadhli A, Barklis RL, Barklis E: HIV-1 matrix organizes as a hexamer of trimers on membranes containing phosphatidylinositol- $(4,5)$ bisphosphate. Virology 2009, 387(2):466-72.

88. Hermida-Matsumoto L, Resh MD: Human immunodeficiency virus type 1 protease triggers a myristoyl switch that modulates membrane binding of Pr55(gag) and p17MA. J Virol 1999, 73(3):1902-8.

89. Resh MD: A myristoyl switch regulates membrane binding of HIV-1 Gag. Proc Natl Acad Sci USA 2004, 101(2):417-8.

90. Fledderman EL, Fujii K, Ghanam RH, Waki K, Prevelige PE, Freed EO, Saad JS: Myristate Exposure in the Human Immunodeficiency Virus Type 1 Matrix Protein Is Modulated by pH. Biochemistry 2010.

91. Ghanam RH, Fernandez TF, Fledderman EL, Saad JS: Binding of calmodulin to the HIV-1 matrix protein triggers myristate exposure. J Biol Chem 2010

92. Datta SAK, Curtis JE, Ratcliff W, Clark PK, Crist RM, Lebowitz J, Krueger S, Rein A: Conformation of the HIV-1 Gag protein in solution. J Mol Biol 2007, 365(3):812-24.

93. Datta SAK, Zhao Z, Clark PK, Tarasov S, Alexandratos JN, Campbell SJ, Kvaratskhelia M, Lebowitz J, Rein A: Interactions between HIV-1 Gag molecules in solution: an inositol phosphate-mediated switch. J Mol Biol 2007, 365(3):799-811

94. Ako-Adjei D, Johnson MC, Vogt VM: The retroviral capsid domain dictates virion size, morphology, and coassembly of gag into virus-like particles. J Virol 2005, 79(21):13463-72.

95. Crist RM, Datta SAK, Stephen AG, Soheilian F, Mirro J, Fisher RJ, Nagashima K, Rein A: Assembly properties of human immunodeficiency virus type $1 \mathrm{Gag}$-leucine zipper chimeras: implications for retrovirus assembly. J Virol 2009, 83(5):2216-25.

96. Ono A, Freed EO: Binding of human immunodeficiency virus type $1 \mathrm{Gag}$ to membrane: role of the matrix amino terminus. J Virol 1999, 73(5):4136-44.

97. Gerlach H, Laumann V, Martens S, Becker CFW, Goody RS, Geyer M: HIV-1 Nef membrane association depends on charge, curvature, composition and sequence. Nat Chem Biol 2010, 6:46-53.

98. Yezid H, Konate K, Debaisieux S, Bonhoure A, Beaumelle B: Mechanism for HIV-1 Tat insertion into the endosome membrane. J Biol Chem 2009, 284(34):22736-46.
99. Rayne F, Debaisieux S, Bonhoure A, Beaumelle B: HIV-1 Tat is unconventionally secreted through the plasma membrane. Cell Biol Int 2010, 34(4):409-13.

100. Rayne F, Debaisieux S, Yezid H, Lin YL, Mettling C, Konate K, Chazal N, Arold ST, Pugniere M, Sanchez F, Bonhoure A, Briant L, Loret E, Roy C, Beaumelle B: Phosphatidylinositol-(4,5)-bisphosphate enables efficient secretion of HIV-1 Tat by infected T-cells. EMBO J 2010, 29(8):1348-62.

101. Richieri SP, Bartholomew R, Aloia RC, Savary J, Gore R, Holt J, Ferre F, Musil R, Tian HR, Trauger R, Lowry P, Jensen F, Carlo DJ, Maigetter RZ, Prior CP: Characterization of highly purified, inactivated HIV-1 particles isolated by anion exchange chromatography. Vaccine 1998, 16(2-3):119-29.

102. Aloia RC, Jensen FC, Curtain CC, Mobley PW, Gordon LM: Lipid composition and fluidity of the human immunodeficiency virus. Proc Natl Acad Sci USA 1988, 85(3):900-4

103. Aloia RC, Tian H, Jensen FC: Lipid composition and fluidity of the human immunodeficiency virus envelope and host cell plasma membranes. Proc Natl Acad Sci USA 1993, 90(11):5181-5.

104. Lorizate M, Brugger B, Akiyama H, Glass B, Muller B, Anderluh G, Wieland FT, Kra"usslich HG: Probing HIV-1 membrane liquid order by Laurdan staining reveals producer cell-dependent differences. J Biol Chem 2009, 284(33):22238-47.

105. Brugger B, Krautkrämer E, Tibroni N, Munte CE, Rauch S, Leibrecht I, Glass B, Breuer S, Geyer M, Krausslich HG, Kalbitzer HR, Wieland FT, Fackler OT: Human immunodeficiency virus type 1 Nef protein modulates the lipid composition of virions and host cell membrane microdomains. Retrovirology 2007, 4:70.

106. Saifuddin M, Parker CJ, Peeples ME, Gorny MK, Zolla-Pazner S, Ghassemi M, Rooney IA, Atkinson JP, Spear GT: Role of virion-associated glycosylphosphatidylinositol-linked proteins CD55 and CD59 in complement resistance of cell line-derived and primary isolates of HIV-1. J Exp Med 1995, 182(2):501-9.

107. Ott DE, Coren LV, Kane BP, Busch LK, Johnson DG, Sowder RCn, Chertova EN, Arthur LO, Henderson LE: Cytoskeletal proteins inside human immunodeficiency virus type 1 virions. J Virol 1996, 70(11):7734-43.

108. Chertova E, Chertov O, Coren LV, Roser JD, Trubey CM, Bess JWJ, Sowder RCn, Barsov E, Hood BL, Fisher RJ, Nagashima K, Conrads TP Veenstra TD, Lifson JD, Ott DE: Proteomic and biochemical analysis of purified human immunodeficiency virus type 1 produced from infected monocyte-derived macrophages. J Virol 2006, 80(18):9039-52.

109. Orentas RJ, Hildreth JE: Association of host cell surface adhesion receptors and other membrane proteins with HIV and SIV. AIDS Res Hum Retroviruses 1993, 9(11):1157-65.

110. Jolly C, Sattentau QJ: Human immunodeficiency virus type 1 assembly, budding, and cell-cell spread in T cells take place in tetraspaninenriched plasma membrane domains. J Virol 2007, 81(15):7873-84.

111. Nydegger S, Khurana S, Krementsov DN, Foti M, Thali M: Mapping of tetraspanin-enriched microdomains that can function as gateways for HIV-1. J Cell Biol 2006, 173(5):795-807.

112. Sato K, Aoki J, Misawa N, Daikoku E, Sano K, Tanaka Y, Koyanagi Y: Modulation of human immunodeficiency virus type 1 infectivity through incorporation of tetraspanin proteins. J Virol 2008, 82(2):1021-33.

113. Grigorov B, Attuil-Audenis V, Perugi F, Nedelec M, Watson S, Pique C, Darlix JL, Conjeaud H, Muriaux D: A role for CD81 on the late steps of HIV-1 replication in a chronically infected T cell line. Retrovirology 2009, 6:28.

114. Krementsov DN, Weng J, Lambele M, Roy NH, Thali M: Tetraspanins regulate cell-to-cell transmission of HIV-1. Retrovirology 2009, 6:64.

115. Thali M: The roles of tetraspanins in HIV-1 replication. Curr Top Microbiol Immunol 2009, 339:85-102.

116. Krementsov DN, Rassam P, Margeat E, Roy NH, Schneider-Schaulies J, Milhiet PE, Thali M: HIV-1 assembly differentially alters dynamics and partitioning of tetraspanins and raft components. Traffic 2010.

117. Nermut MV, Wallengren K, Pager J: Localization of actin in Moloney murine leukemia virus by immunoelectron microscopy. Virology 1999, 260:23-34.

118. Ott DE, Coren LV, Johnson DG, Kane BP, Sowder RCn, Kim YD, Fisher RJ, Zhou XZ, Lu KP, Henderson LE: Actin-binding cellular proteins inside human immunodeficiency virus type 1. Virology 2000, 266:42-51.

119. Espenel C, Margeat E, Dosset P, Arduise C, Le Grimellec C, Royer CA Boucheix C, Rubinstein E, Milhiet PE: Single-molecule analysis of CD9 
dynamics and partitioning reveals multiple modes of interaction in the tetraspanin web. J Cell Biol 2008, 182(4):765-76.

120. Wright MD, Moseley GW, van Spriel AB: Tetraspanin microdomains in immune cell signalling and malignant disease. Tissue Antigens 2004, 64(5):533-42.

121. Yang X, Kovalenko OV, Tang W, Claas C, Stipp CS, Hemler ME: Palmitoylation supports assembly and function of integrin-tetraspanin complexes. J Cell Biol 2004, 167(6):1231-40.

122. Cherukuri A, Shoham T, Sohn HW, Levy S, Brooks S, Carter R, Pierce SK: The tetraspanin CD81 is necessary for partitioning of coligated CD19/CD21-B cell antigen receptor complexes into signaling-active lipid rafts. $J$ Immunol 2004, 172:370-80.

123. Cherukuri A, Carter RH, Brooks S, Bornmann W, Finn R, Dowd CS, Pierce SK: $\mathrm{B}$ cell signaling is regulated by induced palmitoylation of CD81. J Biol Chem 2004, 279(30):31973-82.

124. Delaguillaumie A, Harriague J, Kohanna S, Bismuth G, Rubinstein E, Seigneuret M, Conjeaud H: Tetraspanin CD82 controls the association of cholesterol-dependent microdomains with the actin cytoskeleton in T lymphocytes: relevance to co-stimulation. J Cell Sci 2004, 117(Pt 22):5269-82.

125. Munro S: Lipid rafts: elusive or illusive? Cell 2003, 115(4):377-88.

126. Simons K, Vaz WLC: Model systems, lipid rafts, and cell membranes. Annu Rev Biophys Biomol Struct 2004, 33:269-95.

127. Zech T, Ejsing CS, Gaus K, de Wet B, Shevchenko A, Simons K, Harder T: Accumulation of raft lipids in T-cell plasma membrane domains engaged in TCR signalling. EMBO J 2009, 28(5):466-76.

128. Lingwood D, Simons K: Lipid rafts as a membrane-organizing principle. Science 2010, 327(5961):46-50.

129. Campbell S, Gaus K, Bittman R, Jessup W, Crowe S, Mak J: The raftpromoting property of virion-associated cholesterol, but not the presence of virion-associated Brij 98 rafts, is a determinant of human immunodeficiency virus type 1 infectivity. J Virol 2004, 78(19):10556-65.

130. Ding L, Derdowski A, Wang JJ, Spearman P: Independent segregation of human immunodeficiency virus type $1 \mathrm{Gag}$ protein complexes and lipid rafts. J Virol 2003, 77(3):1916-26.

131. Halwani R, Khorchid A, Cen S, Kleiman L: Rapid localization of Gag/GagPol complexes to detergent-resistant membrane during the assembly of human immunodeficiency virus type 1. J Virol 2003, 77(7):3973-84.

132. Holm K, Weclewicz K, Hewson R, Suomalainen M: Human immunodeficiency virus type 1 assembly and lipid rafts: Pr55(gag) associates with membrane domains that are largely resistant to Brij98 but sensitive to Triton X-100. J Virol 2003, 77(8):4805-17.

133. Lindwasser OW, Resh MD: Multimerization of human immunodeficiency virus type $1 \mathrm{Gag}$ promotes its localization to barges, raft-like membrane microdomains. J Virol 2001, 75(17):7913-24.

134. Nguyen DH, Hildreth JE: Evidence for budding of human immunodeficiency virus type 1 selectively from glycolipid-enriched membrane lipid rafts. J Virol 2000, 74(7):3264-72.

135. Ono A, Waheed AA, Freed EO: Depletion of cellular cholesterol inhibits membrane binding and higher-order multimerization of human immunodeficiency virus type $1 \mathrm{Gag}$. Virology 2007, 360:27-35.

136. Pickl WF, Pimentel-Muïnos FX, Seed B: Lipid rafts and pseudotyping. J Virol 2001, 75(15):7175-83.

137. Bhattacharya J, Repik A, Clapham PR: Gag regulates association of human immunodeficiency virus type 1 envelope with detergent-resistant membranes. J Virol 2006, 80(11):5292-300.

138. Feng X, Heyden NV, Ratner L: Alpha interferon inhibits human T-cell leukemia virus type 1 assembly by preventing Gag interaction with rafts. J Virol 2003, 77(24):13389-95.

139. Lingwood D, Kaiser HJ, Levental I, Simons K: Lipid rafts as functional heterogeneity in cell membranes. Biochem Soc Trans 2009, 37(Pt 5):955-60.

140. Ono A: HIV-1 Assembly at the Plasma Membrane: Gag Trafficking and Localization. Future Virol 2009, 4(3):241-257.

141. Waheed AA, Freed EO: Lipids and membrane microdomains in HIVreplication. Virus Res 2009, 143(2):162-76.

142. Ono A, Waheed AA, Joshi A, Freed EO: Association of human immunodeficiency virus type 1 gag with membrane does not require highly basic sequences in the nucleocapsid: use of a novel Gag multimerization assay. J Virol 2005, 79(22):14131-40.
143. Johnson CM, Chichili GR, Rodgers W: Compartmentalization of phosphatidylinositol 4,5-bisphosphate signaling evidenced using targeted phosphatases. J Biol Chem 2008, 283(44):29920-8.

144. Harrist AV, Ryzhova EV, Harvey T, Gonzalez-Scarano F: Anx2 interacts with HIV-1 Gag at phosphatidylinositol $(4,5)$ bisphosphate-containing lipid rafts and increases viral production in 293T cells. PLoS One 2009, 4(3): e5020.

145. Chasserot-Golaz S, Vitale N, Umbrecht-Jenck E, Knight D, Gerke V, Bader MF: Annexin 2 promotes the formation of lipid microdomains required for calcium-regulated exocytosis of dense-core vesicles. Mol Biol Cell 2005, 16(3):1108-19.

146. Menke M, Gerke V, Steinem C: Phosphatidylserine membrane domain clustering induced by annexin A2/S100A10 heterotetramer. Biochemistry 2005, 44(46):15296-303.

147. Zheng YH, Plemenitas A, Linnemann T, Fackler OT, Peterlin BM: Nef increases infectivity of HIV via lipid rafts. Curr Biol 2001, 11(11):875-9.

148. Zheng YH, Plemenitas A, Fielding CJ, Peterlin BM: Nef increases the synthesis of and transports cholesterol to lipid rafts and HIV-1 progeny virions. Proc Natl Acad Sci USA 2003, 100(14):8460-5.

149. Pique C, Lagaudrielare-Gesbert C, Delamarre L, Rosenberg AR, Conjeaud H, Dokhelar MC: Interaction of CD82 tetraspanin proteins with HTLV-1 envelope glycoproteins inhibits cell-to-cell fusion and virus transmission. Virology 2000, 276(2):455-65.

150. Mazurov D, Heidecker G, Derse D: HTLV-1 Gag protein associates with CD82 tetraspanin microdomains at the plasma membrane. Virology 2006, 346:194-204.

151. Mazurov D, Heidecker G, Derse D: The inner loop of tetraspanins CD82 and CD81 mediates interactions with human T cell lymphotrophic virus type 1 Gag protein. J Biol Chem 2007, 282(6):3896-903.

152. Ruiz-Mateos E, Pelchen-Matthews A, Deneka M, Marsh M: CD63 is not required for production of infectious human immunodeficiency virus type 1 in human macrophages. J Virol 2008, 82(10):4751-61.

153. Hemler ME: Tetraspanin functions and associated microdomains. Nat Rev Mol Cell Biol 2005, 6(10):801-11.

154. Chichili GR, Westmuckett AD, Rodgers W: T cell signal regulation by the actin cytoskeleton. J Biol Chem 2010, 285(19):14737-46.

155. Strasner AB, Natarajan M, Doman T, Key D, August A, Henderson AJ: The Src kinase Lck facilitates assembly of HIV-1 at the plasma membrane. $J$ Immunol 2008, 181(5):3706-13.

doi:10.1186/1742-4690-8-15

Cite this article as: Hamard-Peron and Muriaux: Retroviral matrix and lipids, the intimate interaction. Retrovirology 2011 8:15.

\section{Submit your next manuscript to BioMed Central and take full advantage of:}

- Convenient online submission

- Thorough peer review

- No space constraints or color figure charges

- Immediate publication on acceptance

- Inclusion in PubMed, CAS, Scopus and Google Scholar

- Research which is freely available for redistribution 